УДК: 72.032

ББК: 85.11

A43

DOI: 10.18688/aa199-1-17

D. Karelin

\title{
The Reconstruction of the Diocletianic Fortress in Babylon of Egypt: Architectural Decorations and Details
}

\section{Introduction}

The paper is dedicated to the analysis of the architectural details and decorations of the Late Roman fortress of Babylon in Old Cairo. The virtual reconstruction of the fortress (Ill. 24) was created by the team from Moscow Institute of Architecture (Dmitry Karelin, Maria Karelina and Tatiana Zhitpeleva) and the British archeologist and heritage manager Peter Sheehan ${ }^{1}$. The aims of the reconstruction were to show the architectural and constructional features of the best-preserved parts - the southern gatehouse (Ill. 25) and the round towers which flanked the place where Amnis Trajanus joined the Nile (Ill. 26), to classify the corpus of the sources and to show the connection between each source and to present the arguments for our view of the reconstruction.

The aim of the paper is the study of the architectural decorations of the fortress and the examination of their stylistic features. There remain some very interesting details and decorations in the fortress, namely the partly-survived cornice of the pediment of the southern gate and the capitals and cornices of the round towers of the inner atrium. A lion-headed mooring stone was also found. The items which could be located in the outer apses of the round towers are of special interest.

The fortress is located in the district now known as Old Cairo, in the southern part of modern Cairo. It was mentioned and described in a few sources of the $18^{\text {th }}-19^{\text {th }}$ centuries: the description and drawing by Richard Pococke [16], Déscription de l'Égypte [4] and "Illustrations of Cairo" drawn by J. C. Bourne and published in 1840 by Robert Hay ${ }^{2}$ [7]. The fortress has been explored and recorded since the end of the $19^{\text {th }}$ century. Since the $1990 \mathrm{~s}$ archaeological investigations have been conducted together with conservation work and the lowering of the groundwater level in the area. The results and the explanation of their importance for the origins of Cairo were finally published by Peter Sheehan [18].

The earliest mention of a Roman fortification in Babylon can be found in Strabo's Geography. According to him, Babylon was the location for an earlier military camp (Strabo

The reconstruction has been published partially in the proceedings of the conference Virtual Archaeology (2018) [19]. The main results of the work should be published in the proceedings of XXIV Limes Congress (2018) [12].

2 Only the drawing of the southern gate was published in the latter source (the plate's title is "Gate at the Roman fortress of Babylon, today in the Coptic quarter of Cairo"). 


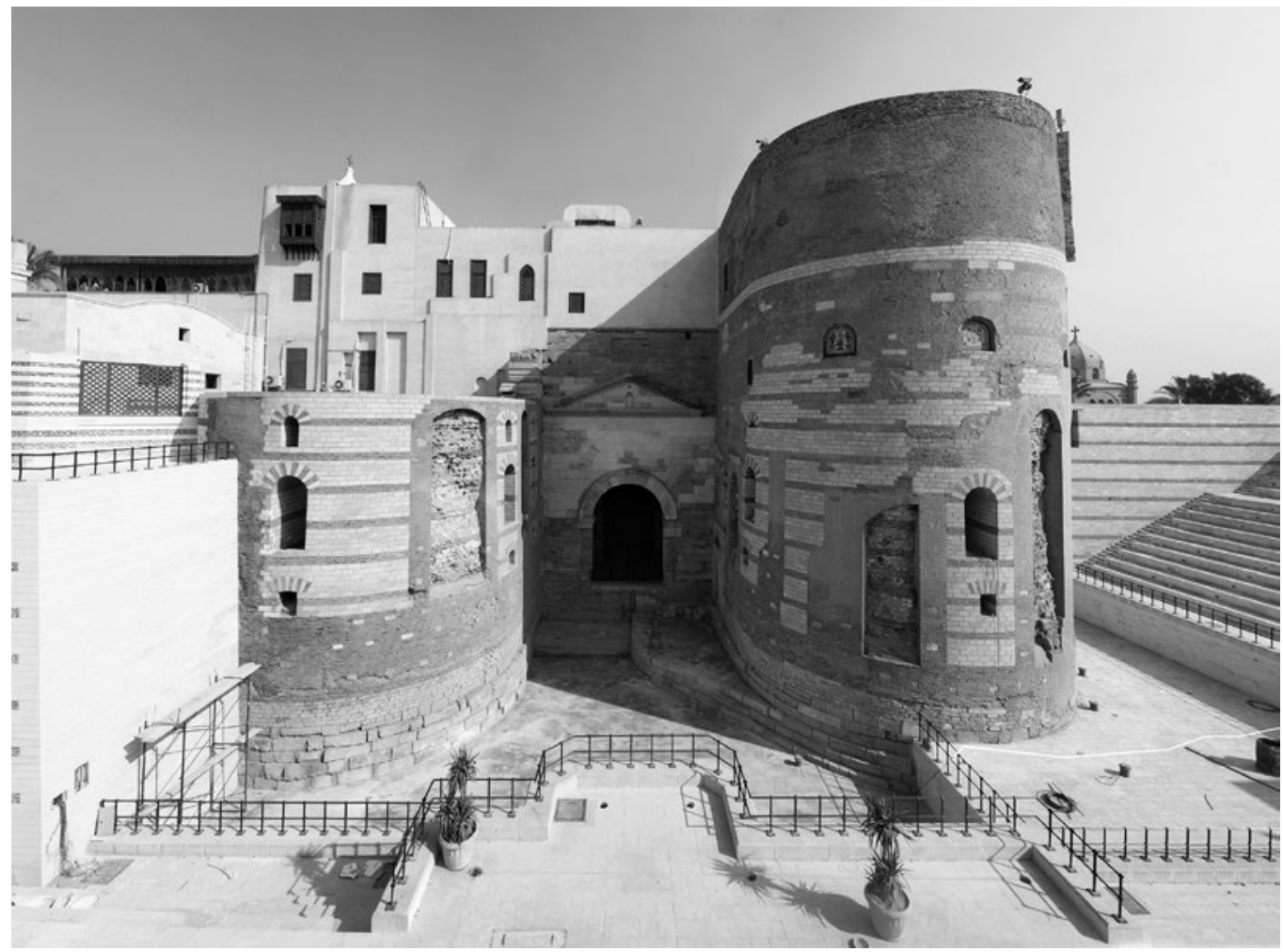

Fig. 1. Southern gate of the fortress of Babylon. Late $3^{\text {rd }}$ - early $4^{\text {th }}$ century. Photo by D. Karelin, 2008

18.1.30). During the reign of Emperor Trajan the entrance to the ancient canal linking the Nile to the Red Sea was shifted to Babylon and a stone harbour with a massive embankment was constructed there. Under Diocletian this entrance to the canal was enclosed within a massive fortress.

The fortress of Babylon was laid out in two parallel enclosures on either side of the canal. In the centre of the southern wall of the eastern enclosure there is a well-preserved gatehouse, above which the Coptic "Hanging Church" (Al-Mu'allaqa) was constructed later. In the southwestern wall there are two round towers flanking the junction of the Nile and the canal. Now one of them accommodates Greek Orthodox Church of St. George (Mari Girgis).

\section{Architectural ornamentation of Babylon fortress}

The portal of the southern gate in Babylon (Fig. 1) was framed with an archivolt resting on pilasters, and above the gate there was a pediment decorated with a cornice. A gatehouse in the fort of Abu Sha'ar in the Egyptian Eastern Desert used to have a similar archivolt [20, p. 56, fig. 3.7].

The decorations of the southern gate of Babylon weren't as rich as those of the Luxor or Nag el-Hagar fortresses, which had pilasters or half-columns. The latter ones, though, couldn't compare in splendor to the gates of some fortresses in Syria or Arabia. However, the gates 
of cities or fortresses were usually adorned with pilasters or half-columns, archivolts and pediments. It might have some reference to their sacral meaning. The territory of a settlement or a fortress was a sacred land for the Romans, and the walls were a border between it and the surrounding world, while the gates served as a passage between these two [8, pp. 11-12; 17, p. 83] $]^{3}$. In Babylon, the quite typical southern gate and the "water gate", situated at the junction of the canal and the Nile and flanked by two round towers, could also have a sacral meaning.

There was a small atrium in the centre of each round tower (Fig. 2), framed by a circular arched colonnade. Several capitals of the columns survived and were found during earlier excavations in the tower, as well as the fragments of the cornice that probably surmounted the arcades. This cornice is very much like the one that topped the pediment of the southern gatehouse.

There were some lion-headed mooring stones in the harbour (Fig. 3). One of them was found during the conservation project. Depictions of similar mooring stones are found on Trajan's column in Rome [18, p. 44, fig. 22, pl. 19].

By the configuration of the outer apses in the round towers we can assume that statues could be set there. We reject the idea of the columns, because the niches were too low and columns of normal proportions wouldn't fit there. The idea of placing standing or sitting statues in the niches seems more appropriate. We suppose they were statues of

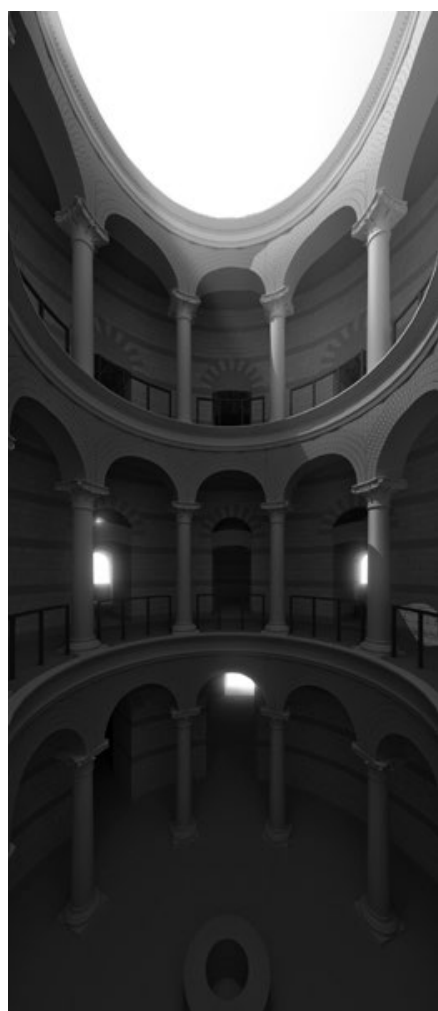

Fig. 2. Atrium of round tower of the fortress of Babylon. Late $3^{\text {rd }}-$ early $4^{\text {th }}$ century. Reconstruction by Dmitry Karelin, Peter Sheehan, Maria Karelina and Tatiana Zhitpeleva Augusts (Diocletian and Maximian), and it is possible that the statues of Caesars (Galerius and Constantius Chlorus) could have been on the opposite junction of the canal and the fortress enclosure. There exist some analogies of such depictions of tetrarchs: the statues in the Vatican Museum and Venice, statues of (possibly) tetrarchs and Jupiter from the niches of the Golden Gate at Split, the five-columned Diocletianic monument from Forum Romanum, sitting statues of Constantine the Great from adlocutio relief from the Arch of Constantine, the porphyry statue of a tetrarch (presumably Galerius) in the Egyptian Museum in Cairo ${ }^{4}$, the porphyry statue of a man sitting on the throne ${ }^{5}$ depicting either Diocletian, Constantine or even Christ ${ }^{6}$ (this one is in a very poor condition), and the porphyry statue in the Museum of Art History in Vienna (Inv. No I 685 [6, pp. 238-239]). We'd like to particularly note the depictions of tetrarchs in the paintings of principia at Luxor [10, pp. 57, 73-77]. There are two types of iconography: either the tetrarchs are portrayed in togas with

For further details see: [9, pp. 132-134].

CG 7257 [21, pp. 6-7; 22, p. 391].

CG 7256 [21, pp. 3-6; 22, p. 17, fig. 24]

For attribution see: [3, Tab. 40; 1, p. 126; 5, p. 17, fig. 24]. 

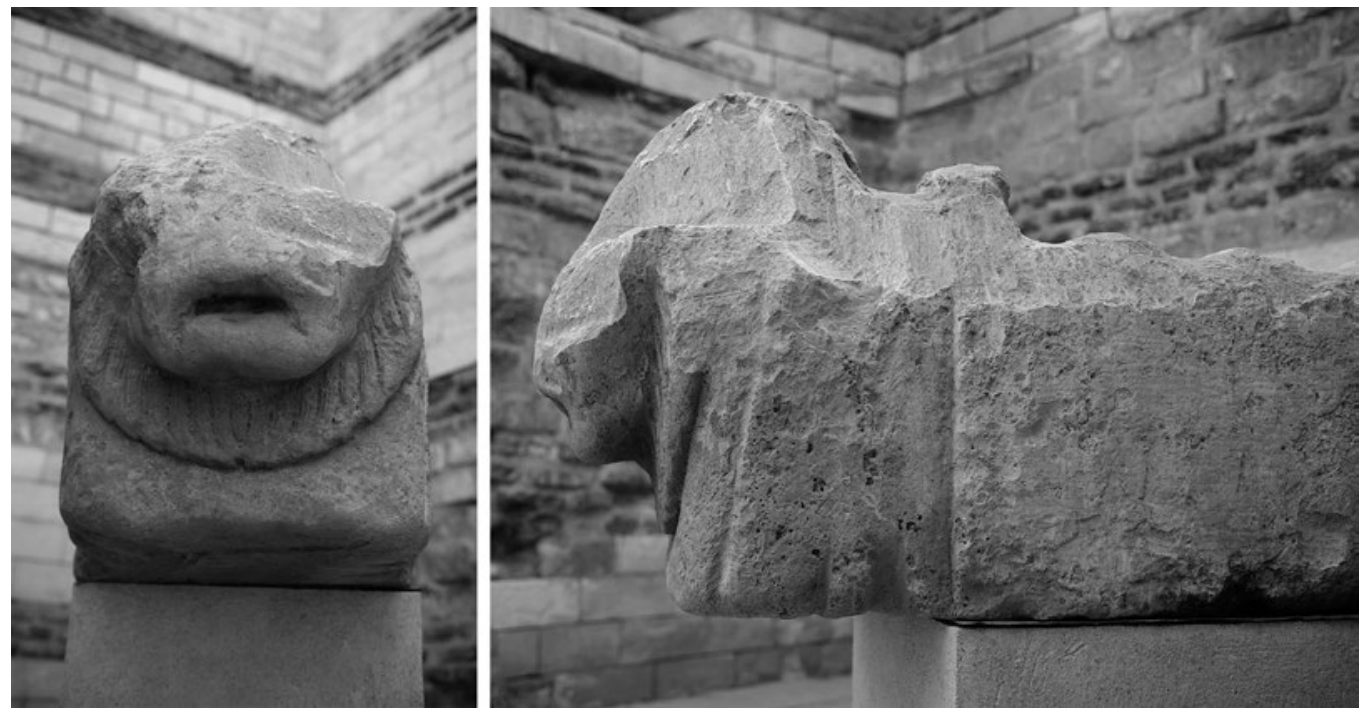

Fig. 3. Lion-headed mooring stone. Courtesy by Peter Sheehan

their attributes of power (as in Luxor, the Arch of Constantine and the Graeco-Roman Museum in Alexandria); or they are painted in armor wearing weapons (as in Vatican and Venice).

We suppose that in Babylon they were most possibly standing statues of the second type, because it used to be a military object, and, besides, they weren't set inside the temple as in Luxor. However, all the surviving examples of such iconography represent two embracing figures and there aren't any examples of individual tetrarchic statues with military attributes. That is why we show them in the same manner as in Luxor.

We would like to draw special attention to the cornices and Corinthian capitals of the southern gate and round towers of Babylon (Fig. 4). During the rule of the Ptolemaic dynasty an original antique school of architecture and sculpture was developed. J. MacKenzie called it the Alexandrian school [13, p. 130; 14, pp. 80-118 $]^{7}$. First of all it is distinguished by a special type of cornice and a special type of the Corinthian capital which are different from the classical Roman Corinthian order. The Corinthian and Ionic orders in the monuments built in the Alexandrian style have a special type of cornice with distinctive narrow flat-grooved modillions alternating with square hollow modillions. It differs from the more ornate cornices of the Roman Corinthian and Ionic orders. At the beginning of the Roman rule this style was the most popular one in Egypt. In typical Alexandrian style capitals the corner volutes and central helixes rise up from the row of acanthus leaves separately, so the cauliculus (the standard element of the Roman Corinthian capital that unites them and from which both volutes and helices emerge) is missing.

In the $2^{\text {nd }}-3^{\text {rd }}$ centuries A.D. architectural style in Egypt developed in two ways [13, p. 135]. The first one was identical to the style that dominated in other Roman Mediterranean prov-

More on stylistic features of architectural details of Roman fortresses in Egypt see: [9]. 
inces where the Roman Corinthian order prevailed. The second school followed traditions established by the architects of the Ptolemaic period. The most characteristic features of this style are those that we can find in Alexandrian architecture beginning from the $2^{\text {nd }}$ century B.C.: cornices with distinctive narrow flat-grooved modillions alternating with square hollow modillions, and capitals without cauliculi, with volutes and helices emerging separately from the row of acanthus leaves.

Now it is time to figure

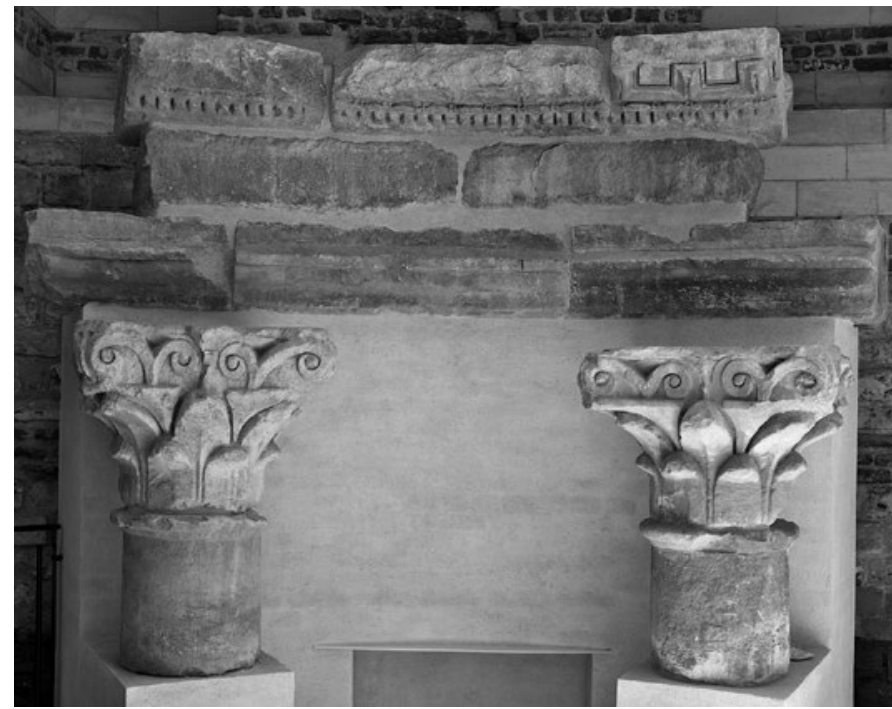

Fig. 4. Cornice and capitals from the atrium of the round tower. Courtesy by Peter Sheehan out which of these styles defined the design of the fortress of Babylon - or at least which style it was closer to.

The cornices of the pediment of the southern gate and the round tower atrium have some typical features of Alexandrian style: narrow flat-grooved modillions alternating with square hollow modillions. As far as we know, these cornices are the only example of Alexandrian style cornices in Roman fortresses. However, there is another example in the temple of Sarapis in Mons Porphyrites, which was built not far from to the fortress in the $2^{\text {nd }}-3^{\text {rd }}$ centuries A.D. [13, p. 135, fig. 4c; 14, p. 223, fig. 387].

But if we examine the Corinthian capitals we will see that they do not look like the capitals characteristic of Alexandrian style ${ }^{8}$. On the contrary, their design is more similar to that of classical Corinthian capitals (Fig. 5). Firstly, they have cauliculi. Secondly, the lower two thirds of the capital consist of acanthus leaves, as on standard capitals one could see in the city of Rome - unlike the Alexandrian type, where acanthus leaves occupy only one third of the capital. We cannot, however, overlook the fact that these capitals were made in rough carving, and even make an impression that they were not quite finished. Such raggedness or unrefined work was more typical of Roman architecture in Egypt ${ }^{9}$. In this respect the examples we study are distinctively different from the most vivid examples of classical Roman Corinthian capitals in Egypt from Hermopolis Magna (el-Ashmunein) [2, p. 16, pl. 14a, 16e], that were very elaborately carved. But the simplicity of design resembles another well-known specimen of a typical capital of the Roman Corinthian order - the one that crowned the honorific column of Pompey in Alexandria, erected in 297 A.D. during the rule of Diocletian [15, p. 214]. Al- 


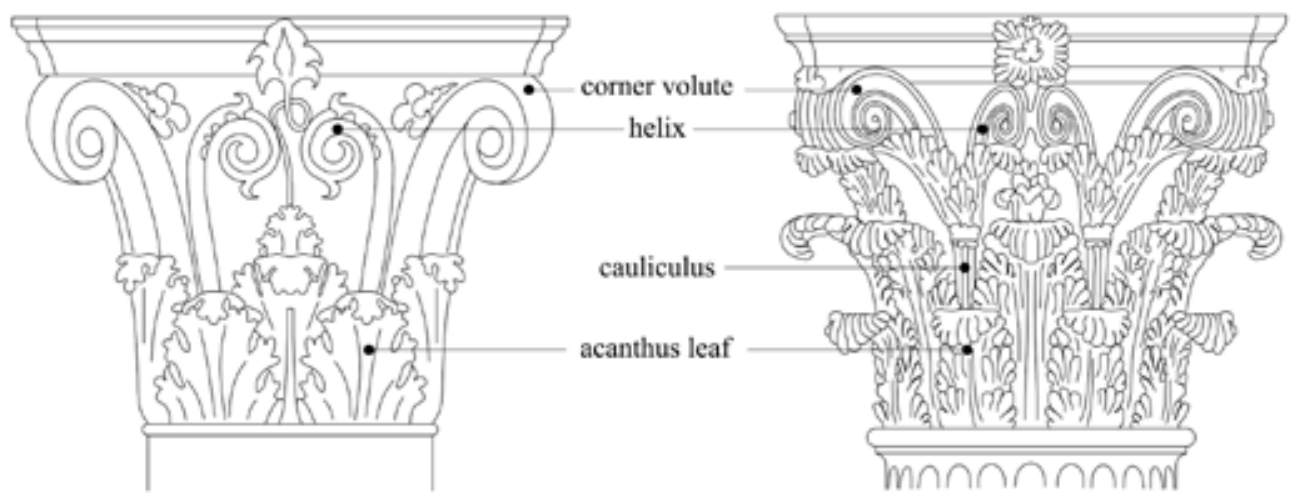

Fig. 5. Left. Alexandrian Corinthian capital. Type I (according J. McKenzie). Right. "Normal" Corinthian capital (based on [14, fig. 125a, 127])

though stone work in this case is, as we already mentioned, simple, and acanthus leaves are not as finely carved as on the capitals from Hermopolis Magna, it is not rough either, as on the capitals from Babylon we examine.

\section{Conclusion}

In conclusion it is necessary to note that the fortress of Babylon was not only furnished with massive fortifications ${ }^{10}$, but also had a rather complicated architectural design. On the one hand, its architecture was evidently influenced by local building tradition, that is, the Alexandrian style. In general, we can trace this influence in other Roman fortresses in Egypt as well, which may be interpreted in two ways: either the architects employed local stone carvers to do the work, or they reused architectural details from some earlier constructions ${ }^{11}$.

On the other hand, the capitals that were found in the fortress are a puzzle yet unsolved, as they were made in rough carving and have the structure of classical Roman Corinthian capitals without the typical features of the Alexandrian style. So far we cannot explain it. We can suggest that the stone carvers brought by Diocletian started to work on the capitals, but for some reason didn't finish them. But we can also presume that it wasn't possible to borrow the capitals from some earlier monument, and the carvers were pressed for time, so that explains the lower quality of work. And it is still possible that the capitals used to be a part of some other monument. Unfortunately, our suggestions don't make it clear why the cornices show the very distinctive characteristics of the Alexandrian style. Only a detailed field examination of all the discovered architectural elements could help to answer these questions.

\section{Acknowledgements}

I am very grateful to my co-authors of the reconstruction Peter Sheehan, Maria Karelina and Tatiana Zhitpeleva. I would especially like to thank Peter Sheehan for the permission to 
use some materials and photos in this publication. Last but not least, I would also like to thank Irina Kulikova for editing the article and for her kind and various assistance and support in every way and Anastasiya Guseva for her inestimable help with the English translation.

\section{References}

1. Alföldi A. Insignien und Tracht der römischen Kaiser. Mitteilungen des Deutschen Archaologischen Instituts (Rom), 1935, vol. 50, pp. 3-158 (in German).

2. Bailey D. M. Hermopolis Magna: Buildings of the Roman Period. London, British Museum Press Publ., 1991. $82 \mathrm{p}$.

3. Delbrueck R. Antike Porphyrwerke. Berlin, De Gruyter Publ., 1932. XXIX, 245 p. (in German).

4. Description de l'Égypte (Electronic resource). Alexandria, Harpocrates Publ., 2005, 1 CD-ROM (in French).

5. Empereur J.-Y. A Short Guide to the Graeco-Roman Museum, Alexandria. Alexandria, Harpocrates Publ., 2000. 37 p.

6. Gschwantler K.; Bernard-Walcher A.; Laubenberger M.; Plattner G.; Zhuber-Okrog K. Masterpieces in the Collection of Greek and Roman Antiquities: A Brief Guide to the Kunsthistorisches Museum. Vienna, Kunsthistorisches Museum Publ., 2012. 271 p.

7. Hay R. Illustrations of Cairo. London, Tilt and Bogue Publ., 1840. 29 pl.

8. Johnson S. Late Roman Fortifications. London, B. T. Batsford Publ., 1983. 315 p.

9. Karelin D. A. Stylistics of Architectural Decoration of Roman Fortresses in Egypt. Ivanov S. V.; Tolmacheva E. G. (eds.). And the Earth is Joyous... Studies in Honour of Galina A. Belova. Moscow, CES RAS Publ., 2015, pp. 129-143.

10. Karelin D. A. The 3D Reconstruction of the Temple of the Roman Imperial Cult inside the Late Roman Fortress at Luxor. Shvidkovsky D. O.; Revzina Yu. E.; Karelin D. A. (eds.). Contemporary Architect and Classical Tradition: Proceedings of the Round Table Held on the $8^{\text {th }}$ of April 2015 at the International Scientific-Practical Conference "Science, Education and Experimental Design" (6-10 of April 2015) at the Moscow Institute of Architecture. Moscow, Moscow Institute of Architecture Publ., 2016, pp. 49-82 (in Russian).

11. Karelin D.; Karelina M.; Zhitpeleva T. Some Problems and Peculiarities of the 3D Reconstruction of the Late Roman Fortresses in Egypt. Sommer S. C.; Matešić S. (eds.). Limes XXIII. Proceedings of the $23^{\text {rd }}$ International Congress of Roman Frontier Studies, Ingolstadt 2015, vol. 1. Mainz, Nünnerich Asmus Publ., 2018, pp. 378-385.

12. Karelin D.; Sheehan P.; Karelina M.; Zhitpeleva T. Babylon of Egypt. The Reconstruction of the Diocletianic Fortress. Proceedings of $24^{\text {th }}$ Limes Congress. Beograd, 2018 (in print).

13. McKenzie J. The Architectural Style of Roman and Byzantine Alexandria and Egypt. Bailey D. M. (ed.). Archaeological Research in Roman Egypt. Ann Arbor, Journal of Roman Archaeology Publ., 1996, pp. 128-142.

14. McKenzie J. The Architecture of Alexandria and Egypt, c. 300 BC to AD 700. New Haven; London, Yale University Press Publ., 2007. 478 p.

15. Phillips J. P. The Columns of Egypt. Manchester, Peartree Publ., 2002. 378 p.

16. Pococke R. A Description of the East, and Some Other Countries, vol. 1: Observations on Egypt. London, W. Bowyer Publ., 1743. 324 p., 73 pl., 2 cartes.

17. Segal A. From Function to Monument. Urban Landscape of Roman Palestine, Syria and Provincia Arabia. Oxford, Oxbow Books Publ., 1997. 192 p.

18. Sheehan P. Babylon of Egypt. The Archaeology of Old Cairo and the Origins of the City. Cairo, The American University in Cairo Press Publ., 2010. 203 p.

19. Sheehan P.; Karelin D.; Karelina M.; Zhitpeleva T. Reconstruction of the Diocletianic Fortress in Babylon of Egypt: Sources and Reconstruction Argumentation. Hookk D. Yu. (ed.). Virtual Archaeology (from Air, on Earth, under Water and at Museum): Proceedings of the International Forum Held at the State Hermitage Museum 28-30 May 2018. St. Petersburg, The State Hermitage Publ., 2018, pp. 224-233.

20. Sidebotham S. E.; Hense M.; Hendrikje M. N. The Red Land. The Illustrated Archaeology of Egypt's Eastern Desert. Cairo, The American University in Cairo Press Publ., 2008. 446 p. 
21. Strzygowski J. Catalogue général des antiquitéségyptiennes du Musée du Caire. Nos. 7001-7394, 8742-9200: Koptische Kunst. Vienne, Holzhausen Publ., 1904. 362 p. (in French).

22. Tiradritti F. (ed.). The Treasures of the Egyptian Museum. Cairo, The American University in Cairo Press Publ., 1999. 416 p.

Title. The Reconstruction of the Diocletianic Fortress in Babylon of Egypt: Architectural Decorations and Details.

Author. Karelin, Dmitry Alexeevich - Ph. D., professor. Moscow Institute of Architecture (State Academy) (MARCHI), Rozhdestvenka ul., 11/4-1-4, 107031 Moscow, Russian Federation. dmitry.a.karelin@gmail.com

Abstract. This paper is dedicated to the virtual reconstruction and the study of architectural ornaments and details of the Late Roman fortress of Babylon. This monument was located in the district now known as Old Cairo. The fortress has been explored and recorded since the end of the $19^{\text {th }}$ century. From the 1990s onwards archaeological investigations have accompanied conservation works and the lowering of groundwater level in the area, and the results of these works were published in 2010.

Babylon was a typical Diocletianic fortress for the field army, however it also possessed a number of unique features. First, it was constructed over the earlier Trajanic-era stone harbour at Babylon where the Amnis Trajanus joined the Nile. The entrance to the canal was flanked by massive round towers. Second, archaeological and historical evidence indicates that the bridge over the Nile led to the western gate of the fortress. Third, the size and strength of the fortifications were much more solid than those of any other Diocletianic fortress in Egypt.

The recent archaeological work has shown that much of the southern part of fortress survives today under the ground. The southern gatehouse on the ground is largely intact, with the Coptic "Hanging Church" (AlMu'allaqa) built over it. The two round towers also survived, one of them within the Greek Orthodox Church of St. George (Mari Girgis).

The aim of the reconstruction was to show the architectural and constructional features of the southern gatehouse and of the round towers flanking the Amnis Trajanus, and also to present the possible view of the fortress from the Nile. Another special aim was to classify the corpus of the sources of information and to show the connection between each source, as well as to visually present the arguments for the reconstruction.

The aim of this paper is to examine and to give arguments for the reconstruction of the architectural decoration of the fortress, and to show their stylistic peculiarities. There are some details and decorations of special interest: the partly surviving cornice of the pediment of the southern gate, the capitals and cornices of the inner atriums in the round towers, the lion-headed mooring stones and the items which could be located in the apses of the round towers.

Keywords: Egypt; Roman fortress; Babylon; Old Cairo; 3D-reconstruction; architectural decorations; architectural details.

Название статьи. Реконструкция позднеримской крепости Вавилон в Египте: архитектурное убранство и детали.

Сведения об авторе. Карелин Дмитрий Алексеевич - кандидат искусствоведения, профессор. Московский архитектурный институт (государственная академия) (МАРХИ), ул. Рождественка, д. 11/4, корпус 1, стр. 4, Москва, Российская Федерация, 107031. dmitry.a.karelin@gmail.com

Аннотация. Статья посвящена реконструкции и анализу архитектурного убранства позднеримской крепости Вавилон. Руины этого памятника располагаются в районе, известном сегодня как Старый Каир. Начиная с конца XIX в. крепость неоднократно исследовалась, а с 1990-х гг. здесь проводились систематические археологические исследования, совмещенные с работами по реконструкции и консервации района Старого Каира и понижению уровня грунтовых вод на ее территории. Результаты этих работ были опубликованы.

С одной стороны, Вавилон представлял собой типичную крепость диоклетиановского времени, однако, с другой, имел ряд уникальных особенностей. Во-первых, крепость была построена поверх ранней каменной набережной времен Траяна в том месте, где древний канал Amnis Trajanus соединялся с Нилом. Во-вторых, археологические и письменные источники свидетельствуют, что мост через Нил вел к западным воротам крепости. В-третьих, укрепления крепости были намного массивнее, чем у любой другой диоклетиановской крепости для comitates в Египте.

Последние археологические исследования показали относительно неплохую сохранность южной части крепости ниже современного уровня земли. Выше уровня земли относительно неплохо сохранились южные ворота с построенной над ними коптской «Висящей церковью» (аль-Муалла- 
ка), а также две круглые башни, одна из которых была превращена в греческую церковь Св. Георгия (Мари Гиргис).

Цели выполненной нами реконструкции заключались прежде всего в рассмотрении архитектурных и конструктивных особенностей наиболее сохранившихся южных ворот, круглых башен, фланкировавших Amnis Trajanus. Также была поставлена задача показать, как крепость могла восприниматься со стороны Нила. Отдельной задачей является классификация имеющихся источников и иллюстрация степени аргументированности отдельных решений, принятых в реконструкции.

Цель статьи заключается в том, чтобы подробно рассмотреть аргументацию реконструкции архитектурного убранства и деталей и показать их стилистические особенности. Особого внимания заслуживают следующие элементы: частично сохранившийся карниз фронтона южных ворот, капители и карнизы атриума круглых башен, каменные блоки для швартовки кораблей с завершением в виде головы льва и неизвестные элементы (статуи или триумфальные колонны?), которые могли быть установлены во внешних апсидах круглых башен.

Ключевые слова: Египет; римская крепость; Вавилон; Старый Каир; 3D-реконструкция; архитектурное убранство; архитектурные детали. 


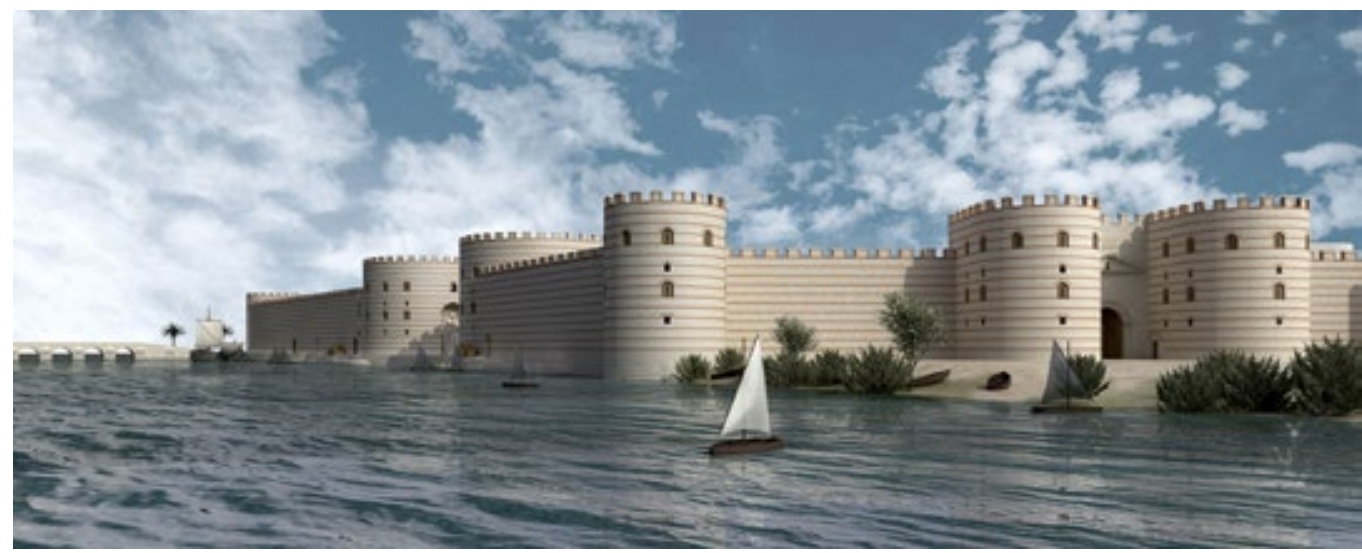

III. 24. Roman fortress of Babylon in Egypt. View from the Nile (from the South-West). Late $3^{\text {rd }}$ - early $4^{\text {th }}$ century. Reconstruction by Dmitry Karelin, Peter Sheehan, Maria Karelina and Tatiana Zhitpeleva

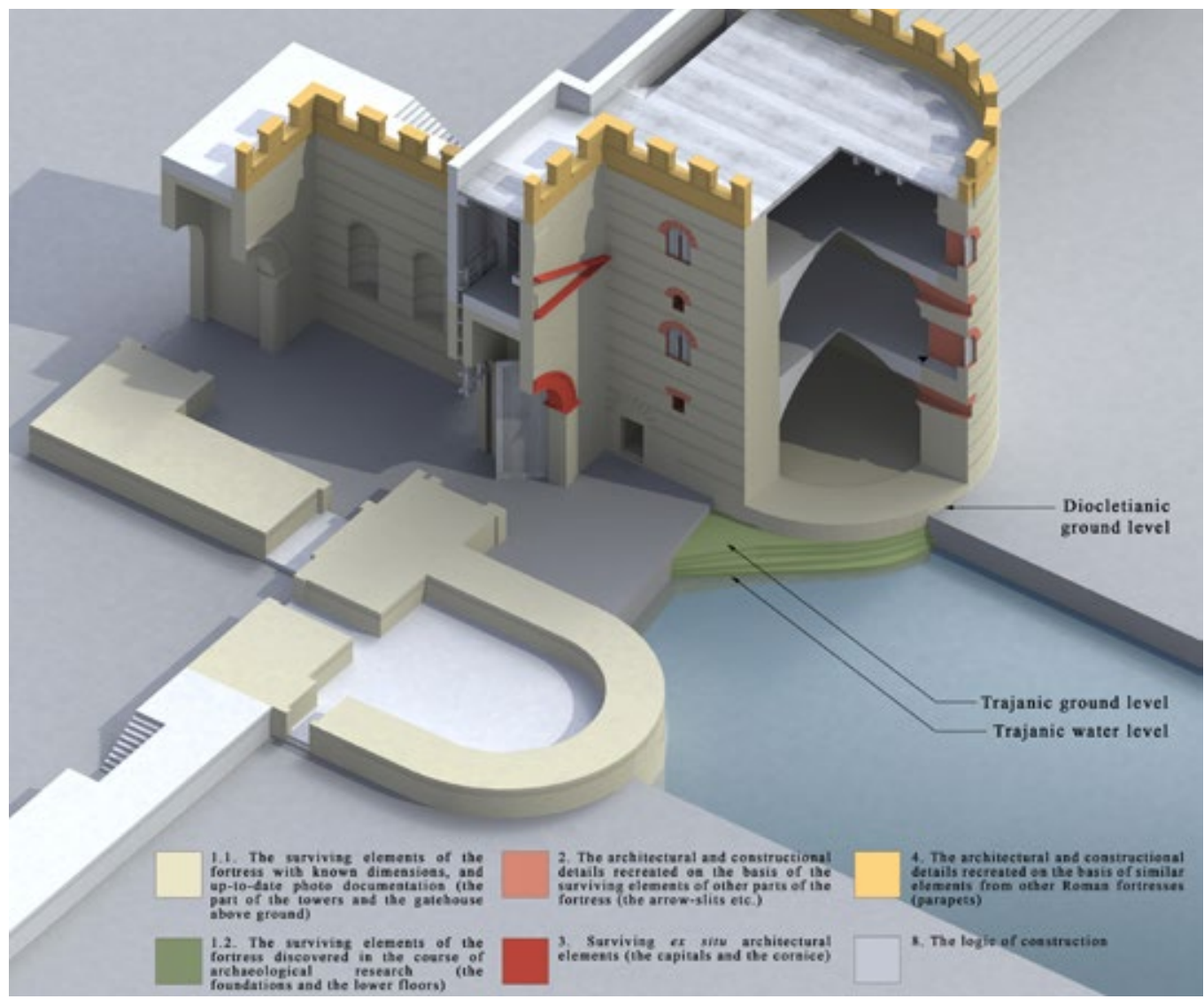

III. 25. Southern gate of the fortress of Babylon. Axonometric view. 3D-modelling reconstructive conjecture uncertainty map. Late $3^{\text {rd }}$ - early $4^{\text {th }}$ century. Reconstruction by Dmitry Karelin, Peter Sheehan, Maria Karelina and Tatiana Zhitpeleva 


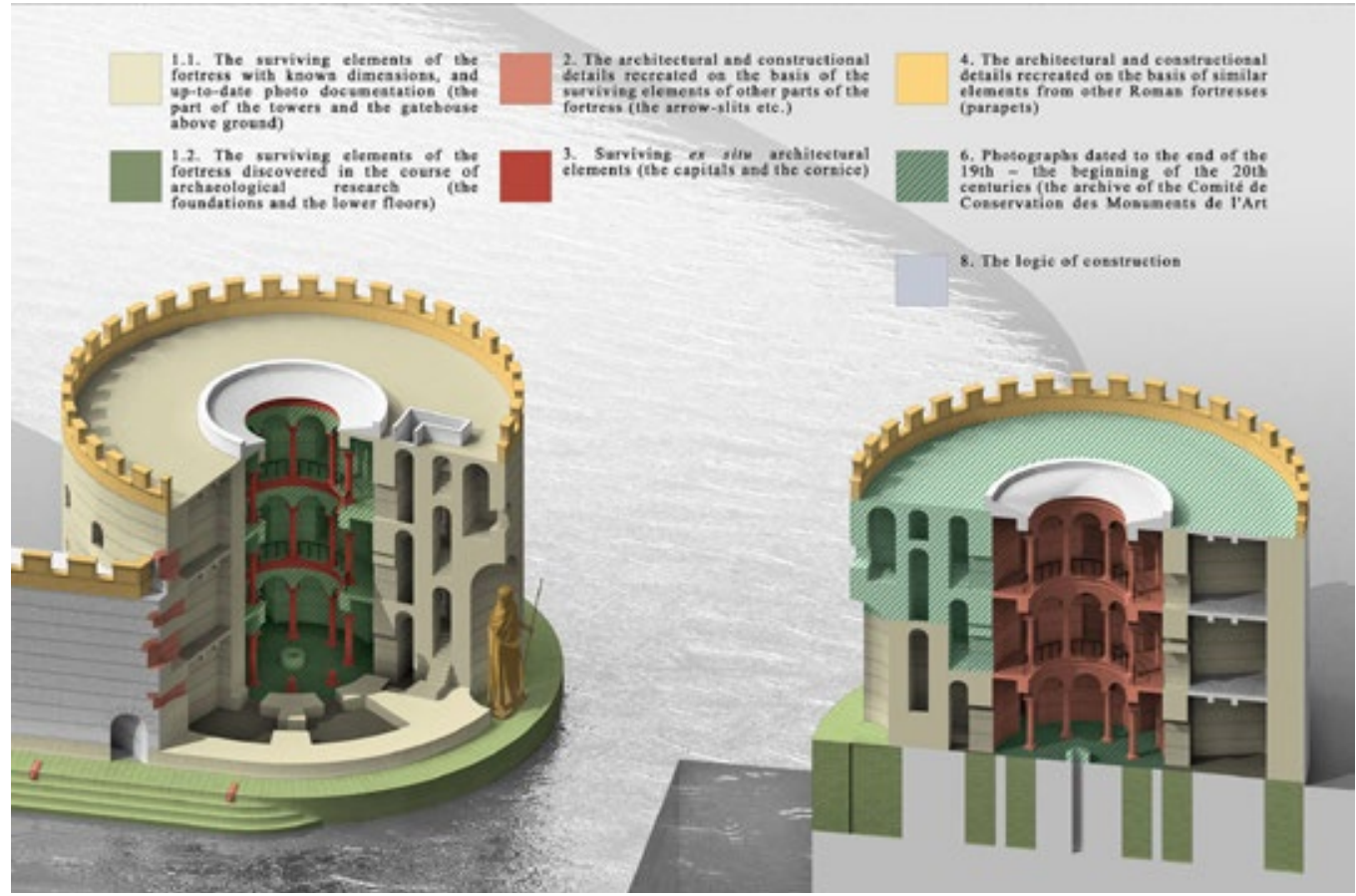

III. 26. Round towers of the fortress of Babylon. Axonometric view. 3D-modelling reconstructive conjecture uncertainty map. Late $3^{\text {rd }}$ - early $4^{\text {th }}$ century. Reconstruction by Dmitry Karelin, Peter Sheehan, Maria Karelina and Tatiana Zhitpeleva

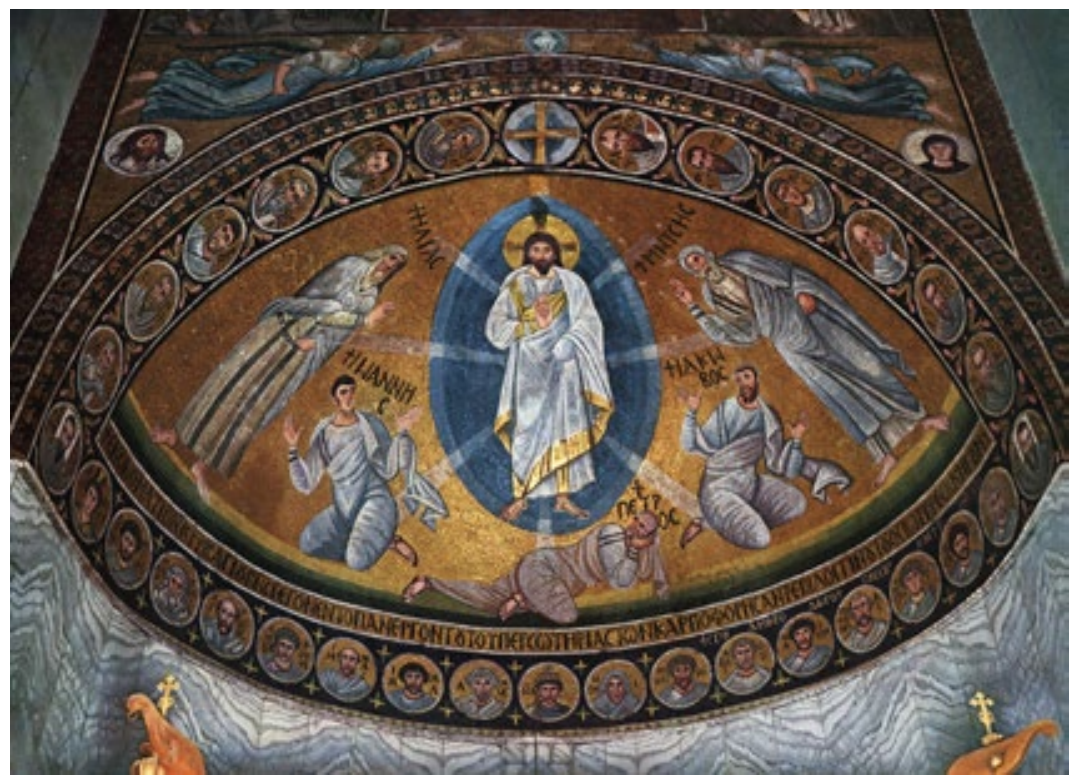

III. 27. Transfiguration in the apse. Church of Saint Catherine on Mount Sinai. Photo by Fanny Vitto 